\title{
On doing what is just, right and fair
}

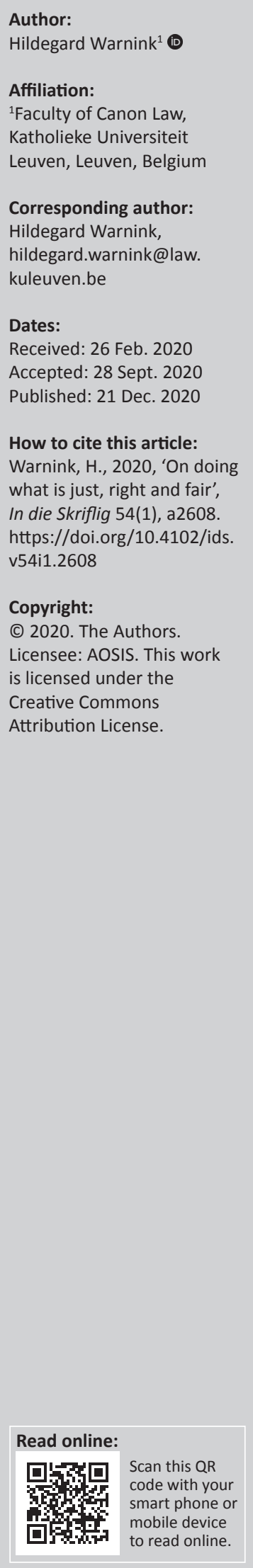

'Just', 'right' and 'fair' are complex concepts without singular definitions. This article investigated these concepts from the perspective of Roman Catholic canon law. The historical and theological contexts of the Roman Catholic Church (the Church) are set within these concepts, which should be understood. Within this context, the notion of 'justice' in the Church is described in four different steps. The first step is a description of the difficult concept of truth and the role of divine law within it. Then, the norm of law is discussed, including the space left for notions such as equity and the salvation of souls. Furthermore, exceptions to the law will be examined, with special attention to both privilege and dispensation. Finally, the custom contra legem will be described as a last possibility for doing justice in the event of unjust laws.

Notions like 'just', 'right' and 'fair' are of utmost importance. Yet at the same time, absolute certainty on the content of the three important notions quoted in the title cannot be achieved - historical context, personal life and unexpected circumstances. They all play a role in offering the right definition. There is no clear definition of what is 'just', 'right' or 'fair', neither from a 'moral theological' or 'ethical' point of view, nor from 'the perspective of the Law'. That is perhaps the correct starting point. People should not be alarmed when good intentions regarding justice lead to different outcomes.

Keywords: Law; Canon law; Ecclesiastical law; Customary law; Divine law.

\section{Introduction: Perspectives from the law of canon}

As a canon lawyer, I may present some observations from the perspective of law, and more specifically from the perspective of ecclesiastical law: the law in the Roman-Catholic church. In my approach, I will start from the system of Roman Catholic canon law and its main principles. It is not an obvious approach and it might differ from other ways of tackling the topic. Two preliminary elements can offer an adequate explanation for these differences:

\section{Canon law is law with a long history and high tenets}

Firstly, the law of the Roman Catholic Church has a long history. Especially in medieval times, it was much more than just a religious legal system. Indeed, in the decades and centuries after the Treaty of Verdun (843 AD), which divided the empire of Charlemagne, Canon Law became the unifying factor in European law. Civil power was spread out, yet religious power was unified. Moreover, that unification also touched upon the secular structures, badly in need of a common legal structure. In later years and centuries, the role of canon law became different and less all-encompassing. Today, the Catholic Church will present itself, less than before, as a societas perfecta. The Code of Canon Law of 1983 remains truly relevant for internal matters, yet the Church tacitly abandoned its aspirations to be entirely self-sufficient, without needing any support of secular powers.

\section{Canon law is serving 'the truth'}

Secondly, Roman Catholic canon law has a self-understanding that goes beyond mere contractual, or other legal aspirations. Indeed, canon law is the legal implementation of a church being convinced of upholding the absolute truth; one can even say the absolute and exclusive truth. Even whilst the Roman Catholic Church recognises baptism as conferred in some other Christian churches, that recognition does not lead to a full acceptance of equality amongst churches. Whilst canon law allows for other Christians to become Catholics, the opposite is not true (Code of Canon Law 1983, canon 11). ${ }^{1}$ In case a Catholic becomes an Anglican or an Orthodox, he will be 1.'Merely ecclesiastical laws bind those baptized in the Catholic Church or received into it and who enjoy the sufficient use of reason and, unless the law expressly provides otherwise, have completed 7 years of age'. 
considered as a schematic or a heretic and will be punished by automatic excommunication (Code of Canon Law 1983, canon 751). ${ }^{2}$ Abandoning 'the truth' remains a crime in the eyes of the Roman Catholic Church (Code of Canon Law 1983, canon $1364 \S 1) .^{3}$

It is needless to say that both elements described above will have an influence on the understanding of what true justice is. The history of Canon law gives it a dignity that at the same time can be rather inflexible. Tradition is sometimes a burden, not always a gift. Moreover, the aspiration of 'truth' makes many options, which at first glance seem to be pastorally useful, impossible, as truth always prevails.

In this I will describe the idea of justice in the Roman Catholic Church in four different steps. The starting point will be the difficult concept of truth and the role divine law plays within it. Then the norm of law will be discussed, including the space left for notions such as equity and the salvation of souls. Thirdly, exceptions to the law will be examined, with special attention to both privilege and dispensation. Eventually, in the fourth chapter, the contra legem custom will be described. It is the last option for doing justice in case the law tends to be unjust.

\section{The truth and divine law}

Few religions and churches are apathetic to find or protect the truth. Yet, in the Roman Catholic Church this aspiration is more developed (cf. Hahn 2012) than, for instance, in a Reformed Tradition, where changing churches is not perceived as a crime. By the way, the fact that it is not seen as criminal has often more to do with the separation of church and state and with a respect for the freedom of conscience, than with a lesser sense of protecting the truth. It should be mentioned that also within Catholic tradition, some discussion on the issue is ongoing. Especially, the still maintained link between truth and exclusivity leads to controversial debates. The central question is, 'can truth exist without being exclusive?' Obviously, the answer is not a simple one as the non-exclusive character of truth may suggest the existence of various forms of truth, which goes against our intuition. Implicitly, in case we believe in truth, we stick to one specific form of it. But then again, the question is more philosophical than theological. Perhaps one could imagine a truth which is absolute without being exclusive. The belief that God was never closer to humans than in the person of Christ could be an example of such an analysis. It leaves room for other forms of God's proximity, without challenging the absolute character of biblical revelation. If anything is relative, it is not truth as such, but the forms of its appearance. There is also a difference between the truth and

2. Heresy is the obstinate post-baptismal denial of some truth which must be believed with divine or catholic faith or it is likewise an obstinate doubt concerning the same; (...) schism is the refusal of submission to the Roman Pontiff or of communion with the members of the Church subject to him'.

3.'An apostate from the faith, a heretic or a schismatic incurs a latae sententiae excommunication, without prejudice to the provision of Can. $194 \$ 1$, n. 2; a cleric, moreover, may be punished with the penalties mentioned in Can. $1336 \S 1, \mathrm{nn} .1,2$ and $3^{\prime}$ our (sinful) human knowledge of it. The latter is the reason for our different views of the same (one) truth.

Why do I discuss this issue? The answer is simple. The more elements of canonical legislation are considered to be part of truth or divine law (eds. Graulich \& Weimann 2018), the more difficult it will be to include an extra constituent of justice in their interpretation. An example can illustrate this idea. In the Catholic Church the indissolubility of marriage is considered to be a part of the divine law. This is literally reflected in the traditional wedding vow: 'till death do us part'. Because of indissolubility, there will be no way out for a marriage that is evidently unhappy. Separation or divorce is impossible. The only way out, in some cases, can be a procedure of reviewing the validity of a marriage. Invalid marriages can be declared null, yet unhappy ones cannot. At first glance, this is where we come to a paradoxical situation. On one hand, God is seen as the summum of mercy, and on the other hand, divine norms - because they are divine - cannot be transgressed, even if an occasional transgression would be more merciful. The result of this paradox is that a divine law gives more possibility to look more closely at what is just, right and fair. Of course, in the meantime, one should expect that norms, belonging to divine law, do not show any weaknesses when it comes to those three important concepts.

What are the norms of divine law? Divine law is understood as deriving from the will of God. According to Thomas Aquinas, divine law comes only from Revelation or Scripture. Norms of divine law in the current Code of Canon Law include the main church structures. The supremacy of the Pope, the leader of the Catholic Church is amongst them. Some derive from that absolute character the impossibility of establishing a separation of powers in the Church. That impossibility could hamper a just or right solution to certain conflicts. In case the supreme judge and the supreme legislator are the same person, the necessary independence may be lacking - an independence needed to avoid the misuse of power. But the position of the Popes can also be interpreted in another way: by focusing on the divine law character of the pontifical office as such, without expanding the divine law status to technical elements, including the separation of powers.

In any case, Roman Catholic canon law has to bear in mind that divine law and justice should go hand in hand. In case the opposite seems to be true, both notions need to be examined in more detail. Is the divine norm as divine as it appears? And what about justice? Do we understand the notion correctly when a clash with divine law seems to be inevitable? The greater the distance, the more unfairness seems to increase.

\section{The norm of law}

Although the role of divine law should never be underestimated, most canonical norms do not have that status and can be interpreted in a way very similar to secular 
legislation. A good example of that similarity is offered by canon 18 of the Code of Canon Law (1983), which is formulated as follows: '[1]aws which establish a penalty or restrict the free exercise of rights or contain an exception of the law, are subject to strict interpretation'.

Here, the objective to reach a just solution is prominently emphasised. Penal norms should remain entirely predictable, also for possible perpetrators. Rights do not depend on the good intentions of people: they are a direct consequence of human existence. It would be unjust to expand penal norms to situations that are different from the literary formulation of the law. For instance, euthanasia, implying the free will of the person who dies, cannot be assimilated with murder. The same is true for the restriction of rights or for other exception to the law. To put it in another way, not only the law itself should be just, but also its interpretation has to offer an additional guarantee ensuring that justice will be done.

However, it may be possible that the norm of law, including an interpretation most favourable to the weak, cannot offer entire satisfaction. In that case, canon law disposes of some technical and legal concepts to refine the process of justice.

\section{Equity}

The first notion is that of 'equity'. At first glance the presence of such a concept is not surprising, as secular legal systems also use it. However, canon law goes a step further and develops a proper concept of equity, the so-called canonical equity (in Latin: aequitas canonica). Canon 19 of the Code of Canon Law (1983) clearly refers to that notion. ${ }^{4}$ When mentioning 'general principles of law applied with canonical equity' as a tool for solving conflicts in case a universal or a particular law is lacking, 'equity' fills a legal gap. At the same time, it is a tool for interpretation of the law. A good example may be the principle 'testis unus, testis nullus' [one witness is no witness]. However, in cases of sexual abuse, this principle may appear to be too strict, considering the intimacy associated with the crime. Interestingly, the Republic of South Africa Bill of Rights concerning freedom of religion (Article 15) also relies on the concept of equity.

Amongst canon lawyers, over the centuries, much discussion took place with regard to the exact meaning of the notion of canonical equity (Wohlhaupter 1931). Is it really that different from equity as perceived by the secular legal systems? Is it more generous? Does it mean 'more Christian' (whatever that may mean)? Probably there is not a true difference in meaning between secular and canonical equity. One could even argue that excessive reliance on canonical equity could endanger a fair implementation of the law. Indeed, in canon law, there have always been

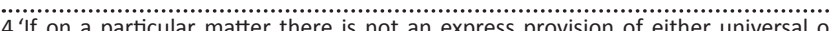
particular law, nor a custom, then, provided it is not a penal matter, the question is particular law, nor a custom, then, provided it is not a penal matter, the question is to be decided by taking into account laws enacted in similar matters, the general principles of law observed with canonical equity, the jurisprudence and practice of the Roman Curia, and the common and constant opinion of learned authors'. tendencies in favour of a pastoral resolution to any conflict. As such, there is nothing wrong with this precept and yet some canon lawyers tend to put common law within brackets and replace it with a so-called pastoral solution. That approach seems very dangerous to me, although it was very much around in the years following the Second Vatican Council. Nowadays, however, most canon lawyers will argue that the first principle of a pastoral approach is a fair application of the law, notwithstanding the possible ethical and other considerations. The recognition of someone's rights is an indispensable element of a truly pastoral attitude by Church authorities. Only if the rights of people are strictly respected that new possibilities can be searched for in a more pastoral context.

\section{The salvation of souls: Salus animarum}

The norm of law can also be enriched by another typically canonical notion, namely, the salvation of souls (in Latin: salus animarum). One could see this notion as a logical counterpart of the divine law principles. The latter are the starting point of the canonical system and, by virtue of its status, limit the margin of freedom the legislator enjoys in promulgating canonical norms. Any law formulated by the legislator has to be in harmony and in full compliance with all divine law norms underpinning the system. The salvation of the souls operates at the other end of the legal process. Here, the starting point and its compatibility with divine law are no longer at stake, but the result of the canonical reasoning is analysed. Is it possible to live with the outcome of the legal reasoning following the canonical norms? Most of the time, the outcome will be, or at least should be, satisfactory, as the norms have divine origin or, at least to a fair extent, not opposed to it. But one never knows, sometimes, perhaps because of the context, or as a result of a specific situation that could not be covered by the law, justice cannot be found. In such a situation, a correction mechanism is still possible, as a result of the attention given to the salvation of the souls. To put it in yet another way, legal reasoning has to give way to the extrinsic outcome leading to the salvation of souls. The very last canon of the Code of Canon Law, canon 1752, refers to the salvation of souls (Althaus 2007) in the context of the transfer of pastors, and immediately broadens its ambit to canonical law in its entirety. Canon 1752 states:

In cases of transfer, the prescripts of canon 1747 are to be applied. Canonical equity is to be observed, and the salvation of souls, which must always be the supreme law in the Church, is to be kept before one's eyes. (n.p.)

Is it not remarkable that both canonical equity and the salvation of the souls are mentioned in the very last canon as a kind of gatekeeper, guaranteeing that ultimate justice will always be done to the Christian faithful?

\section{Privilege and dispensation}

In some cases, the norm of law notwithstanding the implementation of canonical equity and attention paid to the 
salvation of the souls will not offer justice or at least, not as it should be, during this life. It does not mean necessarily that the law is intrinsically unjust. Yet, it shows that one of its main characteristics, namely, its applicability to all, not giving full satisfaction. The law may be just for some people, but not for all of them. There is a need for exceptions, perhaps because of human imperfection. Of course, this need is problematic in itself. The equality principle requires a law ready to cover all possible situations and applicable to all without discrimination.

One can argue that a law unable to achieve this objective is a bad one and should be replaced by a more adequate alternative. This may be an issue leading to deep philosophical reflection. Is a law that falls short of being applicable to all possible situations necessarily a deficient one? Many secular lawyers would answer 'yes' to this question. However, canon law has a more nuanced opinion on it. It accepts the exception in two different forms through two different institutions, namely, privilege and dispensation. Yet at the same time, both are implemented with much caution and even with some form of distrust.

\section{Privilege}

As mentioned, the first notion is privilege. It finds its place in the code of Canon Law in canons 76-84. The chapter remains very short - nine canons altogether, whereas in medieval times, entire books were filled with privileges for people, groups or congregations. After Vatican II, however, the idea of privilege was found entirely at odds with the equality principle, as highlighted by the conciliar fathers of Vatican II. Equality was an issue during the council, including the upgrading of lay people in the Church. The Code of Canon Law also formulates the principle of equality in canon $208^{5}$ (Code of Canon Law 1983). In such a context, privilege truly becomes problematic. Indeed, when someone enjoys a privilege it means that, unlike others, he is not bound by a specific law. Privileges are common in a system where people have different rights and are treated unequally. But when equality emerges, it has no legitimate place any longer.

Notwithstanding the theoretical clash between equality and privilege, the Code of Canon Law maintained privilege as a theoretical possibility, yet without enthusiasm (McCormack 1998). A good illustration can be found in canon 84 , which states: '[o]ne who abuses the power given by a privilege deserves to be deprived of that privilege'.

It is more than likely that in the next version of the Code of Canon Law, privileges will be even more marginalised or could possibly even disappear, as they are seen as being in opposition to true justice. ${ }^{6}$ Equally unlikely is the future

\footnotetext{
5.'Flowing from their rebirth in Christ, there is a genuine equality of dignity and action amongst all of Christ's faithful. Because of this equality they all contribute, each according to his or her own condition and office, to the building up of the Body of Christ'.
}

6.'The acceptance of "privileges" could rather be seen as an admission that we as humans may not be able to formulate the law perfectly'. acceptance of positive discrimination, granting a better position to women or lay people as a compensation for their previously inferior position.

\section{Dispensation}

Apart from privilege, dispensation may be an exception to the law. Dispensation is the relaxation of a merely ecclesiastical law in specific cases. Its impact is much more restricted than the consequences of a privilege. When a dispensation is given, the law as such remains applicable to the person enjoying the dispensation. But he obtains an exception for this one single specific situation. For instance, one can obtain a dispensation when formal elements of a legal act cannot be fulfilled. Or, as it happened often in the past, one can be dispensed to go to church on the next Sunday because he or she is making a trip abroad.

The concept of dispensation is not as unsettling to the system as a privilege can be. A dispensation focuses on very specific forms of justice, at a very specific moment and for very specific people (Adam 2011) but even then, the legislator remains sceptical and endeavours to prevent bishops or other leaders using dispensation to circumvent the application of papal norms. For that reason, a bishop is not able to arbitrate on procedural or penal norms, as mentioned in canon 87 (Code of Canon Law 1983, canon 87 \$1). ${ }^{7} \mathrm{~A}$ dispensation is also subject to strict interpretation as canon 92 says (Code of Canon Law 1983, canon 92). ${ }^{8}$ Moreover, in case a dispensation is given without a just and reasonable cause, it will in many cases be invalid: canon $90 \$ 1$ (Code of Canon Law 1983) is quite strict in this regard. ${ }^{9}$

Both privilege and dispensation are looked at with some scepticism, and rightly so. Their existence as such is very legitimate, although more so for dispensation than for privilege. Secular law also recognises the principle of 'equality by law'. Through unequal treatment it tries to bring those who are unequal to real or more equality. It is this order of equality that is created by positive discrimination. Nonetheless, it is advisable to be cautious and restrictive when making use of it, as justice most of the time is not served by making exception to a legal norm applicable to all. The risk of both privilege and dispensation is that by creating exceptions and by refining a system in search of even more justice, one may achieve the obverse result.

Here we come to a general principle that is discerned through an analysis of canon law. How can concrete justice and the overall application of the law be reconciled? It is in identifying the right equilibrium that the true master can be found.

7. Whenever he judges that it contributes to their spiritual welfare, the diocesan Bishop can dispense the faithful from disciplinary laws, both universal laws and those particular laws made by the supreme ecclesiastical authority for his territory or his subjects. He cannot dispense from procedural laws or from penal laws, nor from those whose dispensation is specially reserved to the Apostolic See or to some other authority'.

8.'A strict interpretation is to be given not only to a dispensation in accordance with can. $36 \S 1$, but also to the very power of dispensing granted for a specific case'.

9.'A dispensation from an ecclesiastical law is not to be given without a just and reasonable cause, taking into account the circumstances of the case and the importance of the law from which the dispensation is given; otherwise the dispensation is unlawful and, unless given by the legislator or his superior, it is also invalid'. 


\section{Custom against the law}

There may be situations in which justice is truly hard to find. In these cases, even the combination of the three elements described above turns out to be insufficient to reach true justice. Here, canon law offers a last remedy, namely, the custom against the law (Urrutia 1981).

Not all legal systems offer such a possibility. And it may sound surprising that the Roman Catholic Church, relying on the truth for many norms, offers at the same time the openness for the apparently anarchist technique such as the custom against the law. A community capable of receiving a law can develop a custom obtaining force of law in case the faithful observe it with the intention of introducing a law (Code of Canon Law 1983, canon 25). ${ }^{10}$ The system is not without restrictions. Canon $24 \S 1$ clearly says that 'no custom which is contrary to divine law can obtain the force of law'.

Here again, very similar to the legal norm, the custom finds itself bound by the context and framework of divine law. But within that context, the custom is not necessarily weaker than the law. Moreover, in case the legislator, through his laws, fails to offer justice, the community of faithful can take recourse to justice by reason of custom against the law. The expediency of this custom is not an overly strong one; rather, on occasions it turns out to be quite vulnerable. The legislator can always interrupt the development of a custom against the law. At the same time, even after the interruption, the growing of a new custom, at least in most cases, can depart again. A good example of a custom against a law is the practice that lay people can preach the homily in the liturgy, notwithstanding the reservation of such practice to a priest or deacon in canon $767 \S 1$ (Code of Canon Law 1983). ${ }^{11}$

\section{Conclusion}

What is just, right and fair? Canon law tackles this issue in various ways. It starts from divine law, which is unfailing in its dispensation of justice or fairness. But afterwards, in its legal system, canon law leaves many possibilities for the establishment of justice in case the norm fails. The starting point remains the equitable quality of a norm applicable to all. Yet, aequitas canonica and salus animarum can refine the principle. Privilege and dispensation can even formulate exceptions to a legal norm applicable to all. Much caution will always be necessary. Yet, exceptions to the law remain in order to achieve more justice. As a last solution, the custom against the law is offered as a possible recourse. The system appears to be solid, but does it guarantee that justice will always be bestowed? That is certainly not the case as many weaknesses in the canonical system illustrate. Sexual abuse, the enforcement of rights and the struggle against financial fraud all show how

10.'No custom acquires the force of law unless it has been observed, with the intention of introducing a law, by a community capable at least of receiving a law'.

11.'The most important form of preaching is the homily, which is part of the liturgy, and is reserved to a priest or deacon. In the course of the liturgical year, the mysteries of faith and the rules of Christian living are to be expounded in the homily from the sacred text'. difficult it is to achieve true justice, even though the aspiration of achieving it remains very high.

Justice is not just a matter of norms and their application, including exceptions. It should also be present in the thoughts, in the heart and in the actions of all people involved. The Church cannot impose it on its own. That would not lead to true sustainability. Only a sense of justice nestled in people's hearts leads to justice and fairness: knowing that 'to do what is right and just is more acceptable to the LORD than sacrifice' (Pr 21:3).

\section{Acknowledgements Competing interests}

The author declares that she has no financial or personal relationships that may have inappropriately influenced her in writing this research article.

\section{Author's contribution}

H.W. is the sole author of this research article.

\section{Ethical considerations}

This article followed all ethical standards for research without direct contact with human or animal subjects.

\section{Funding information}

This research received no specific grant from any funding agency in the public, commercial or not-for-profit sectors.

\section{Data availability}

Data sharing is not applicable to this article as no new data were created or analysed in this study.

\section{Disclaimer}

The views and opinions expressed in this article are those of the author and do not necessarily reflect the official policy or position of any affiliated agency of the author.

\section{References}

Adam, W., 2011, Legal flexibility and the mission of the church: Dispensation and flexibility in ecclesiastical law, Routledge, London.

Althaus, R., 2007, 'Salus Animarum Suprema Lex', Archiv für katholisches Kirchenrecht 176(1), 316-321. https://doi.org/10.30965/2589045X-17601038

Code of Canon Law, 1983, viewed n.d., from https://www.vatican.va/archive/ ENG1104/_INDEX.HTM.

Graulich, M. \& Weimann, R. (eds.), 2018, Ewige Ordnung in sich verändernder Gesellschaft? Das göttliche recht im theologischen Diskurs, Herder, Freiburg.

Hahn, J., 2012, “"Gesetz der Wahrheit”. Rechtstheoretische Überlegungen in Anschluss an aktuelle päpstliche Äusserungen zur Rechtsbegründung', Archiv für katholisches Kirchenrecht 181(1), 106-128. https://doi.org/10.30965/2589045X-18101009

McCormack, A., 1998, The term 'privilege'. A textual study of its meaning and use, Gregorian \& Biblical Press, Rome.

Urrutia, F.J., 1981, 'De consituedine canonica novi canones studio proponuntur', Periodica 70(1), 69-103.

Wohlhaupter, E., 1931, Aequitas canonica, Schöningh, Paderborn. 